\title{
INTEGRASI PAJAK DAN ZAKAT DI INDONESIA
}

\author{
Muhammad Rheza Ramadhan \\ Politeknik Keuangan Negara-STAN \\ Email:rhezakz@gmail.com
}

\begin{abstract}
Abstrak. Integrasi Pajak Dan Zakat Di Indonesia. Pemungutan dan pengelolaan zakat saat ini dilakukan oleh Badan Amil Zakat Nasional dan dibantu oleh Lembaga Amil Zakat yang didirikan masyarakat. Hal ini tentu menjadi permasalahan karena seharusnya pemerintah lah yang berkewajiban untuk melakukan pemungutan dan pengelolaan zakat. Kemudian dalam pengelolaannya pun dana zakat masih belum dikelola dengan baik, bahkan terkesan terdapat suatu bidang yang dibiayai baik oleh zakat maupun oleh pajak. Hal ini disebabkan oleh belum terintegrasinya sistem pajak dan zakat di Indonesia baik dalam pemungutannya maupun pengelolaannya. Penelitian ini menunjukkan bahwa terdapat beberapa belanja pemerintah yang dapat dibiayai oleh zakat sehingga dengan pemungutan dan pengelolaan zakat yang lebih baik, mengakibatkan adanya perbaikan dalam defisit anggaran pemerintah dan saldo utang pemerintah yang semakin berkurang. Selain itu, penelitian ini memberikan usulan mengenai integrasi sistem pemungutan pajak dan zakat di Indonesia serta bagaimana hubungan antara zakat dan pajak dalam hal kewajiban pemenuhannya yang terutang kepada seseorang atau suatu badan yang sama.
\end{abstract}

Kata Kunci: Zakat, Pajak, Integrasi, APBN, Penerimaan Negara.

Abstract. The Property in Islam (Imam Muhammad Abu Zahrah's Perspective). Based on an observation through many communities, it is obviously that people are very careless on the possession of property, or even merely to get the advantage from it. They used not to think about, but prefer to neglect, the rightness of owning, the rightness of acquiring and the rightness of spending the property. In their mind is whatever they can gain, irrespective to the ethic and moral on the way of reaching and gaining, is totally belong to them, and they are free to do so ever. It is a very liberal concept of property. As a way of life, Islamic order ruled all aspects of life including the ownership of the property. There many verses of Al Qur'an as well as the teaching of the prophet Muhammad PBUH about the property. Imam Muhammad Abu Zahrah, the famous and prominent Egyptian muslim scholar in the first twentieth century who has great intention and desire of the implementation of Islamic law was one who has keen interest on the issue of economy, especially on the issue of usury (riba). He has written several articles, papers and a book as well, on the subject of riba. Moreover, he has also written a set of Qur'anic Interpretation in which he commented on some verses concerning the property and wealth

Keywords: Property, Provision, Infaq, Sadaqah. 


\section{Pendahuluan}

Zakat dan pajak merupakan dua hal yang memiliki kesamaan, yaitu keduanya merupakan bagian pendapatan yang diambil dari wajib pajak dan wajib zakat untuk membiayai suatu kebutuhan tertentu. Negara Kesatuan Republik Indonesia mengartikan pajak sebagai kontribusi wajib kepada negara yang terutang oleh orang pribadi atau badan yang bersifat memaksa berdasarkan Undang-Undang dengan tidak mendapatkan imbalan secara langsung dan digunakan untuk keperluan negara bagi sebesar-besarnya kemakmuran rakyat, sedangkan At-Tuwajiri $(125,2012)$ menjelaskan pengertian zakat secara bahasa sebagai berkembang dan bertambah, sedangkan zakat secara istilah berarti hak wajib pada harta tertentu untuk golongan tertentu di waktu tertentu. Pengelolaan pajak di Indonesia saat ini dibagi menjadi dua, pertama pemerintah pusat, dalam hal ini diwakili oleh Direktorat Jenderal Pajak (DJP), mengelola Pajak Penghasilan, Pajak Pertambahan Nilai, Pajak Penjualan atas Barang Mewah, Bea Meterai, dan Pajak Bumi dan Bangunan-P3, sedangkan pajak lainnya seperti Pajak Bumi dan Bangunan-P2, BPHTB, Pajak Restoran, dan sebagainya dikelola oleh Pemerintah Daerah. Sedangkan pengelola zakat menurut UndangUndang nomor 23 tahun 2011 adalah Badan Amil Zakat Nasional (BAZNAS) dan Lembaga Amil Zakat (LAZ) yang didirikan oleh masyarakat.

Adanya dualisme pengelolaan zakat dan pajak oleh dua lembaga yang berbeda menyebabkan adanya ketidaksinkronan antara pajak dengan zakat dan efek buruk yang lain, diantaranya pertama, zakat tidak dapat digunakan pemerintah untuk mendanai kegiatan pemerintah karena pengelola zakat menyerahkan zakat secara langsung kepada masyarakat sehingga hal ini menyebabkan adanya dualisme kegiatan yang dibiayai dengan zakat namun juga dibiayai oleh APBN yang bersumber dari pajak, kedua, pemungutan zakat masih jauh dari optimal, BAZNAS, dalam laman resminya, menyatakan bahwa potensi zakat Indonesia mencapai 3,4\% dari Produk Domestik Bruto (PDB), PDB Indonesia pada tahun 2014 mencapai 10.542,7 triliun rupiah, artinya potansi zakat seharusnya mencapai angka 358,45 triliun rupiah, padahal zakat yang dipungut pada tahun 2014 hanya sebesar 82,94 triliun rupiah, artinya persentase penerimaan zakat hanya mencapai $23,13 \%$. Ketiga, zakat yang saat ini dipungut baik oleh BAZNAS maupun LAZ mayoritas merupakan zakat 
Muhammad Reza Ramadhan: Integrasi Pajak dan...

penghasilan, padahal masih banyak terdapat jenis zakat lain yang dapat dipungut yang belum dapat terjangkau baik oleh BAZNAS maupun LAZ.

Pemungutan dan pengelolaan zakat sebenarnya merupakan tanggung jawab pemerintah setidaknya hal ini disampaikan oleh Al-Qardhawi (2011, 545), AlMawardi (2006, 201), dan An-Nabahan (2000,111). Oleh karena itu, pemerintah seharusnya dapat mengintegrasikan sistem zakat ke dalam sistem penerimaan negara yang sudah ada. Dengan adanya hal tersebut perlu kiranya penulis melakukan riset tentang integrasi zakat dan pajak di Indonesia. Adapun penelitian ini diharapkan dapat menjawab beberapa permasalahan sebagai berikut: pertama, seberapa penting zakat dijadikan sebagai sumber penerimaan negara dan kedua, bagaimana mengintegrasikan sistem pemungutan pajak dan zakat di Indonesia.

\section{Metode}

Dalam menjelaskan kedua pertanyaan penelitian di atas, penulis menggunakan metode studi pustaka dan sebisa mungkin akan membawakan dalil-dalil dari Alquran, hadis nabi, ijma, qiyas, dan perkataan para ulama-ulama yang telah diakui kebesarannya di tengah kaum muslim. Hal ini didasarkan kepada pernyataan AlUtsaimin $(2005,82)$ yaitu bahwa urutan pengambilan dalil terdiri dari Alquran dan hadis, apabila dalam Alquran dan hadis hal tersebut belum ditentukan secara jelas, maka diperbolehkan menggunakan ijma' (kesepakatan umat muslim) dan dilanjutkan dengan qiyas.

\section{Pembahasan}

\section{Pentingnya Zakat Sebagai Sumber Penerimaan Negara}

Pentingnya zakat untuk dikelola sebagai suatu sumber penerimaan negara setidaknya dapat dilihat dari beberapa hal berikut: pertama, objek pemungutan zakat, kedua, pihak-pihak yang dapat menerima zakat, dan ketiga, motivasi pemenuhan kewajiban zakat.

\section{a. Objek Zakat}

Dalil dari Alquran tentang diwajibkannya zakat adalah sesuai yang Allah sampaikan dalam surat 9: 103, "Ambillah zakat dari sebagian harta mereka, dan berdoalah untuk mereka." Jenis-jenis objek zakat sebagaimana disebutkan oleh Al- 
Islamiconomic: Jurnal Ekonomi Islam

Vol.8 No.1 Januari - Juni 2017

$\overline{\text { Bugho }(2009,182) \text { adalah sebagai berikut, pertama, binatang ternak , kedua, barang }}$ berharga, ketiga hasil pertanian, keempat, hasil buah-buahan, dan kelima, barang dagangan. Kemudian Al-Qardawi $(2011,170)$ menambahkan beberapa jenis objek zakat yang tidak diatur secara eksplisit dalam Alquran dan hadis yaitu zakat barang tambang dan hasil laut, zakat investasi pabrik, zakat pencairan dan profesi, serta zakat saham dan obligasi.

Kemudian, zakat akan dipungut atas objek zakat jika dan hanya jika memenuhi beberapa ketentuan sebagaimana disampaikan oleh Salim $(2006,16)$ yaitu pertama, harta objek zakat telah mencapai nishab, yaitu kadar yang telah ditetapkan oleh syariat akan wajibnya zakat setelah nishab terlampaui, kedua harta dimiliki secara utuh dan sempurna oleh pemiliknya.

Sedangkan objek pemungutan pajak hanya terbatas kepada penghasilan, pertambahan nilai, penjualan barang mewah, bea meterai, serta bumi dan bangunan untuk pajak pusat. Sedangkan untuk pajak daerah meliputi pajak kendaraan bermotor, bea balik nama kendaraan bermotor, pajak bahan bakar kendaraan bermotor, pajak air permukaan, dan pajak rokok untuk pajak provinsi, kemudian pajak hotel, pajak restoran, pajak hiburan, pajak reklame, pajak penerangan jalan, pajak mineral bukan logam dan batuan, pajak parkir, pajak air tanah, pajak sarang burung walet, pajak bumi dan bangunan perdesaan dan perkotaan, dan bea perolehan hak atas ranah dan Bangunan.

Oleh karena itu, jika kita membandingkan antara objek pajak dan objek zakat, terdapat perbedaan yang cukup signifikan, sebagaimana ditampilkan dalam tabel di bawah ini:

Tabel 1 Perbandingan Objek Pajak dan Zakat

\begin{tabular}{|l|c|c|}
\hline \multicolumn{1}{|c|}{ Jenis Objek } & Objek Zakat & Objek Pajak \\
\hline Binatang ternak & $\mathrm{V}$ & $\mathrm{X}$ \\
\hline $\begin{array}{l}\text { Barang berharga (emas dan } \\
\text { perak) }\end{array}$ & $\mathrm{V}$ & $\mathrm{X}$ \\
\hline Hasil pertanian & $\mathrm{V}$ & $\mathrm{X}$ \\
\hline Hasil buah-buahan & $\mathrm{V}$ & $\mathrm{X}$ \\
\hline Barang dagangan & $\mathrm{V}$ & $\mathrm{X}$ \\
\hline
\end{tabular}


Muhammad Reza Ramadhan: Integrasi Pajak dan...

\begin{tabular}{|c|c|c|}
\hline Jenis Objek & Objek Zakat & Objek Pajak \\
\hline Barang tambang dan hasil laut & V & $\mathrm{V}(\mathrm{PDRD})$ \\
\hline Investasi pabrik dan gedung & V & $V(P B B)$ \\
\hline Penghasilan & V & $\mathrm{V}(\mathrm{PPh})$ \\
\hline Saham dan obligasi & V & $\mathrm{X}$ \\
\hline Pertambahan Nilai & $\mathrm{X}$ & $\mathrm{V}(\mathrm{PPN})$ \\
\hline $\begin{array}{l}\text { Bumi dan Bangunan selain } \\
\text { pabrik dan gedung }\end{array}$ & $\mathrm{X}$ & $\mathrm{V}(\mathrm{PBB})$ \\
\hline Penjualan barang mewah & $\mathrm{X}$ & $\mathrm{V}(\mathrm{PPn}-\mathrm{BM})$ \\
\hline Kendaraan bermotor & $\mathrm{X}$ & $\mathrm{V}$ (PDRD) \\
\hline $\begin{array}{l}\text { Bahan bakar kendaraan } \\
\text { bermotor }\end{array}$ & $\mathrm{X}$ & $\mathrm{V}$ (PDRD) \\
\hline Air permukaan & $\mathrm{X}$ & $\mathrm{V}(\mathrm{PDRD})$ \\
\hline Rokok & $\mathrm{X}$ & V (PDRD) \\
\hline Hotel & $\mathrm{X}$ & $\mathrm{V}(\mathrm{PDRD})$ \\
\hline Hiburan & $\mathrm{X}$ & $\mathrm{V}(\mathrm{PDRD})$ \\
\hline Reklame & $\mathrm{X}$ & $\mathrm{V}(\mathrm{PDRD})$ \\
\hline Penerangan jalan & $\mathrm{X}$ & V (PDRD) \\
\hline Air tanah & $\mathrm{X}$ & $\mathrm{V}$ (PDRD) \\
\hline Sarang burung walet & $\mathrm{X}$ & $\mathrm{V}(\mathrm{PDRD})$ \\
\hline
\end{tabular}

Dari data pada tabel di atas, dapat dilihat bahwa mayoritas objek zakat yang tidak menjadi objek pajak, sehingga masih banyak potensi penerimaan negara yang masih dapat digali dari objek zakat yang tidak dikenai pajak. Oleh karena itu, dengan data di atas, pemerintah dapat meningkatkan penerimaan negaranya dengan meningkatkan upaya pemungutan zakat di masyarakat.

\section{b. Alokasi Dana Zakat}

Setelah sebelumnya penulis membahas mengenai perbandingan antara objek pajak dan zakat. Maka, dalam bagian ini penulis akan menyampaikan pentingnya zakat bagi penerimaan suatu negara dari segi belanja apa saja yang dapat dibiayai 
Islamiconomic: Jurnal Ekonomi Islam

Vol.8 No.1 Januari - Juni 2017

dengan zakat. Dalam APBN 2016 dianggarkan belanja negara Rp 1.325,6 Triliun, sebagaimana dibagi menurut fungsi sebagai berikut:

Tabel 2 Pembagian Belanja Berdasarkan Fungsi

\begin{tabular}{|c|c|}
\hline Belanja & Nilai Belanja (Rp) \\
\hline Belanja perlindungan sosial & $158 \mathrm{~T}$ \\
\hline Pelayanan umum & $316 \mathrm{~T}$ \\
\hline Pertahanan & $99,6 \mathrm{~T}$ \\
\hline Ketertiban dan keamanan & $109,8 \mathrm{~T}$ \\
\hline Ekonomi & $360,2 \mathrm{~T}$ \\
\hline Lingkungan hidup & $12,1 \mathrm{~T}$ \\
\hline Agama & $9,8 \mathrm{~T}$ \\
\hline $\begin{array}{lll}\text { Pariwisata dan } & \text { Ekonomi } \\
\text { Kreatif } & & \end{array}$ & $7,4 \mathrm{~T}$ \\
\hline Pendidikan & $150,1 \mathrm{~T}$ \\
\hline Kesehatan & $67,2 \mathrm{~T}$ \\
\hline $\begin{array}{l}\text { Perumahan dan ekonomi } \\
\text { kreatif }\end{array}$ & $7,4 \mathrm{~T}$ \\
\hline Transfer ke daerah & $770,2 \mathrm{~T}$ \\
\hline Jumlah & $2095,7 \mathrm{~T}$ \\
\hline
\end{tabular}

Sedangkan menurut jenis belanja, belanja pemerintah pusat dibagi sebagai berikut:

Tabel 3 Pembagian Belanja Menurut Jenis

\begin{tabular}{|l|c|}
\hline Belanja & Nilai Belanja (Rp) \\
\hline Belanja pegawai & $347,5 \mathrm{~T}$ \\
\hline Belanja barang & $325,4 \mathrm{~T}$ \\
\hline Belanja modal & $201,6 \mathrm{~T}$ \\
\hline Pembayaran bunga utang & $184,9 \mathrm{~T}$ \\
\hline Subsidi & $182,6 \mathrm{~T}$ \\
\hline Belanja hibah & $4 \mathrm{~T}$ \\
\hline Belanja bantuan sosial & $54,9 \mathrm{~T}$ \\
\hline Belanja lain-lain & $24,7 \mathrm{~T}$ \\
\hline
\end{tabular}


Dengan belanja yang begitu besar, pendapatan negara sebesar Rp 1.822 Triliun belum mampu mencukupi seluruh belanja yang dibutuhkan oleh pemerintah. Oleh karena itu, pemerintah harus menganggarkan pembiayaan karena defisit APBN sebesar Rp 273,7 Triliun.

Kemudian, dimisalkan persentase potensi zakat terhadap PDB pada tahun 2016 sama dengan persentase tahun 2014 yaitu 3,4\% dari PDB, kemudian pada tahun 2016, diasumsikan tingkat pertumbuhan ekonomi mampu mencapai tingkat pertumbuhan sesuai dengan asumsi ekonomi makro yang telah ditetapkan yaitu sebesar 5,7\%. Maka, PDB pada tahun 2016 akan mencapai Rp 12.198,6 Triliun (data BPS), sehingga potensi zakat dapat mencapai angka Rp 414,75 Triliun. Maka, jika zakat digunakan untuk penerimaan negara, maka pemerintah akan mengalami surplus sebesar Rp 141,05 Triliun.

Hanya saja, terdapat pertanyaan, apakah zakat dapat digunakan untuk membiayai belanja pemerintah? Allah telah menyebutkan dalam Alquran bahwa penerima harta zakat terdiri dari orang fakir, orang miskin, 'amil (pemungut zakat), mu'allaf (orang yang baru masuk islam), memerdekakan budak, orang yang berhutang, fi sabilillah (orang yang berperang untuk membela islam), dan ibnu sabil (musafir yang kehabisan biaya perjalanan). Oleh karena itu, banyak ulama dan para ahli ekonomi mengatakan bahwa penggunaan zakat sangat terbatas dan tidak dapat memenuhi kebutuhan belanja pemerintah.

Namun, banyak pula ulama yang memperluas cakupan dari orang yang berhak menerima zakat dengan menggunakan qiyas, misalnya adalah Ibnu Rusyd sebagaimana dikutip oleh Al-Qardhawi $(2011,561)$ menganalogikan antara pegawai negeri dan pejabat negara dengan 'amil zakat. Oleh karena itu zakat dapat digunakan untuk membiayai penghasilan dari pegawai negeri dan pejabat negara yang melakukan pekerjaannya untuk kepentingan masyarakat. Selain itu, pengertian fi sabilillah juga dapat dipersamakan dengan belanja untuk pertahanan dan keamanan, hal ini sebagaimana disampaikan oleh Ibnu Arabi, Abdul Hakam, dan An-Nawawi sebagaimana dikutip dalam Al-Qardhawi $(2011,613)$. Selain itu, Al-Qardhawi (2011, 642) juga menganalogikan belanja di bidang kebudayaan, pendidikan, dan penerangan dengan $f i$ sabilillah asalkan belanja tersebut digunakan untuk 
Islamiconomic: Jurnal Ekonomi Islam

Vol.8 No.1 Januari - Juni 2017

kepentingan islam, Selain itu, menurut Al-Qardhawi $(2011,661)$ termasuk juga pengertian dari ibnu sabil, yaitu orang yang diusir dari negara lain dan meminta suaka dan tuna wisma.

Oleh karena itu, dari penjelasan di atas dapat disimpulkan, menurut pendapat para ulama yang didasarkan dengan qiyas, zakat dapat digunakan untuk membiayai pengeluaran-pengeluaran pemerintah selain yang disebutkan di Alquran. Oleh karena itu, belanja pemerintah yang dapat dibiayai dengan zakat menurut fungsinya adalah sebagai berikut:

Tabel 4 Identifikasi Belanja yang Dapat Dibiayai dengan Zakat Menurut Fungsinya

\begin{tabular}{|c|c|c|c|}
\hline Jenis Belanja & $\begin{array}{ll}\text { Nilai } & \text { Belanja } \\
\text { (Rp) } & \end{array}$ & Bisa/Tidak & Keterangan \\
\hline $\begin{array}{l}\text { Belanja } \\
\text { perlindungan sosial }\end{array}$ & $158 \mathrm{~T}$ & Bisa & \\
\hline Pelayanan umum & $316 \mathrm{~T}$ & Tidak & \\
\hline Pertahanan & $99,6 \mathrm{~T}$ & Bisa & \\
\hline $\begin{array}{ll}\text { Ketertiban } & \text { dan } \\
\text { keamanan } & \end{array}$ & $109,8 \mathrm{~T}$ & Bisa & \\
\hline Ekonomi & $360,2 \mathrm{~T}$ & Tidak & \\
\hline Lingkungan hidup & $12,1 \mathrm{~T}$ & Tidak & \\
\hline Agama & $9,8 \mathrm{~T}$ & Bisa & $\begin{array}{l}\text { Digunakan } \\
\text { untuk } \\
\text { kepentingan } \\
\text { islam }\end{array}$ \\
\hline $\begin{array}{l}\text { Pariwisata dan } \\
\text { Ekonomi Kreatif }\end{array}$ & $7,4 \mathrm{~T}$ & Tidak & \\
\hline Pendidikan & $150,1 \mathrm{~T}$ & Bisa & $\begin{array}{l}\text { Digunakan } \\
\text { untuk } \\
\text { pendidikan } \\
\text { umat muslim }\end{array}$ \\
\hline Kesehatan & $67,2 \mathrm{~T}$ & Tidak & \\
\hline $\begin{array}{ll}\text { Perumahan } & \text { dan }\end{array}$ & $7,4 \mathrm{~T}$ & Tidak & \\
\hline
\end{tabular}


Muhammad Reza Ramadhan: Integrasi Pajak dan...

\begin{tabular}{|l|c|l|l|}
\hline ekonomi kreatif & & & \\
\hline Transfer ke daerah & $770,2 \mathrm{~T}$ & Tidak & \\
\hline
\end{tabular}

Sedangkan, menurut jenisnya, belanja yang dapat dibiayai oleh zakat adalah sebagai berikut:

Tabel 5 Identifikasi Belanja yang Dapat Dibiayai dengan Zakat Menurut Jenisnya

\begin{tabular}{|c|c|c|c|}
\hline Jenis Belanja & $\begin{array}{l}\text { Nilai } \quad \text { Belanja } \\
\text { (Rp) }\end{array}$ & Bisa/Tidak & Keterangan \\
\hline Belanja pegawai & $347,5 \mathrm{~T}$ & Bisa & $\begin{array}{l}\text { Digunakan } \\
\text { untuk } \\
\text { kemaslahatan } \\
\text { masyarakat } \\
\text { muslim }\end{array}$ \\
\hline Belanja barang & $325,4 \mathrm{~T}$ & Bisa & $\begin{array}{l}\text { Digunakan } \\
\text { untuk } \\
\text { kemaslahatan } \\
\text { masyarakat } \\
\text { muslim }\end{array}$ \\
\hline Belanja modal & $201,6 \mathrm{~T}$ & Bisa & $\begin{array}{l}\text { Digunakan } \\
\text { untuk } \\
\text { kemaslahatan } \\
\text { masyarakat } \\
\text { muslim }\end{array}$ \\
\hline $\begin{array}{l}\text { Pembayaran bunga } \\
\text { utang }\end{array}$ & $184,9 \mathrm{~T}$ & Tidak & \\
\hline Subsidi & $182,6 \mathrm{~T}$ & Tidak & \\
\hline Belanja hibah & $4 \mathrm{~T}$ & Tidak & \\
\hline $\begin{array}{l}\text { Belanja bantuan } \\
\text { sosial }\end{array}$ & $54,9 \mathrm{~T}$ & Bisa & \\
\hline Belanja lain-lain & $24,7 \mathrm{~T}$ & Tidak & \\
\hline
\end{tabular}


Islamiconomic: Jurnal Ekonomi Islam

Vol.8 No.1 Januari - Juni 2017

Oleh karena itu, dapat disimpulkan walaupun zakat belum mencukupi untuk membiayai seluruh belanja pemerintah yang dapat dibiayai oleh zakat, penerimaan dari zakat tetap menjadi sangat berarti untuk membiayai belanja pemerintah karena dapat mengurangi defisit anggaran yang dialami oleh pemerintah atau bahkan mengubah anggaran pemerintah yang sebelumnya defisit menjadi surplus.

\section{c. Motivasi Pemenuhan Kewajiban Zakat}

Pentingnya zakat sebagai sumber penerimaan negara juga dapat dilihat dari besarnya motivasi kaum muslimin untuk membayar zakat. Bakar dan Rahman (2007, 34) dan Al-Qardhawi (2011, 1002) menjelaskan bahwa umat muslim membayar zakat karena kecintaan mereka kepada Allah dan pengharapan untuk mendapatkan pahala. Berbeda dengan zakat, pemerintah harus menerapkan aturan-aturan yang ketat agar masyarakat bersedia membayar pajak karena pada dasarnya hampir semua orang tidak bersedia membayar pajak jika tidak dipaksa. Oleh karena itu, dengan adanya perbedaan tersebut, pemerintah akan lebih mudah dalam memungut zakat dibandingkan dengan memungut pajak.

\section{Mengintegrasikan Pajak dan Zakat: Suatu Rekomendasi}

Setelah di bagian sebelumnya, penulis menyajikan pentingnya zakat sebagai sumber penerimaan di suatu negara, maka pada bagian ini penulis akan menampilkan rekomendasi atas sistem pemungutan zakat di Indonesia yang terdiri dari pihak yang harus melakukan pemungutan dan administrasi zakat, pihak yang harus mengelola dana zakat, dan hubungan antara zakat dengan pajak.

\section{a. Pihak yang Bertanggung jawab}

Dalam sahih bukhori, terdapat sebuah hadis yang menjelaskan secara jelas mengenai pihak yang bertanggung jawab atas pemungutan zakat di Indonesia yaitu sebuah hadis yang diriwayatkan dari sahabat Ibnu Abbas sebagaimana dikutip oleh Al-Qardhawi (2011, 735): “beritahukan kepada mereka, bahwa Allah telah mewajibkan dari sebagian harta-harta mereka, untuk disedekahkan. Diambil dari orang kaya untuk diberikan kepada mereka yang fakir. Apabila mereka menaatimu dalam hal ini, maka peliharalah akan kedermawanan harta mereka dan takutlah akan doa orang yang teraniaya." Ibnu Hajar sebagaimana dikutip dalam Al-Qardhawi 
Muhammad Reza Ramadhan: Integrasi Pajak dan...

(2011, 735) menjelaskan bahwa hadis di atas menjelaskan kewajiban pemerintah dalam memungut zakat atas masyarakatnya baik secara langsung atau diwakilkan oleh suatu lembaga lain, dan apabila terdapat orang yang enggan membayar zakat, maka pemerintah harus mengambil zakat dari orang tersebut secara paksa. Oleh karena itu, dapat disimpulkan bahwa tanggung jawab pemerintah dalam pemungutan zakat terdiri dari pertama, pembuatan aturan mengenai pemungutan zakat, kedua, melakukan pengawasan terhadap zakat yang dibayar oleh masyarakat, ketiga, melakukan penegakan hukum terhadap orang yang enggan membayar zakat dan membayar zakat dengan jumlah yang kurang dari seharusnya, dan melakukan pengelolaan dana zakat dan mendistribusikannya kepada pihak yang berhak menerima.

Pemerintah sebagai pihak yang bertanggung jawab terhadap pemungutan dan pengelolaan dana zakat harus menentukan perwakilan pemerintah yang bertanggung jawab terhadap pemungutan zakat dan administrasi serta pengawasan wajib zakat. Indonesia saat ini mengandalkan BAZNAS dan LAZ sebagai pemungut dana zakat, pengelola, serta pendistribusi dana zakat dan sebagaimana yang telah penulis sebutkan di bagian pendahuluan, penerimaan zakat hanya mencapai 23,13\% dari potensi yang seharusnya dapat dipungut. Maka dari itu, perlu adanya suatu lembaga khusus yang hanya bertugas untuk pemungutan zakat dan administrasi zakat yang terpisah dari pendistribusi dana zakat dengan kriteria sebagai berikut:

1) Lembaga tersebut berada di bawah Kementerian Keuangan

Lembaga tersebut harus berada dibawah kementerian keuangan sebagai bentuk adanya integrasi fiskal antara pajak dengan zakat. Kementerian keuangan selaku penanggung jawab kebijakan fiskal akan lebih mudah mengatur kebijakan yang akan diambil apabila lembaga pemungutan zakat berada di bawah Kementerian Keuangan. 2) Lembaga tersebut dapat disatukan dengan Direktorat Jenderal Pajak

Mengingat adanya kesamaan fungsi antara zakat dengan pajak, lembaga pemungut zakat dan pajak dapat disatukan dalam satu organisasi karena hal ini tentunya lebih efisien dibandingkan dengan membentuk suatu lembaga baru yang khusus menjalankan pemungutan pajak. Selain itu, dengan sebaran Kantor Pelayanan Pajak yang berada di seluruh Indonesia, akan lebih mengefektifkan pemungutan zakat apabila di dalam Kantor Pelayanan Pajak ditambahkan fungsi baru yang 
Islamiconomic: Jurnal Ekonomi Islam

Vol.8 No.1 Januari - Juni 2017

melakukan pemungutan zakat. Apabila lembaga pemungut zakat digabungkan ke dalam Direktorat Jenderal Pajak perlu ditambahkan beberapa unit organisasi baru di dalam Direktorat Jenderal Pajak, diantaranya:

a) Membentuk suatu sub direktorat di Direktorat Peraturan Perpajakan I/II yang memiliki fungsi untuk membuat regulasi terkait pemungutan zakat

b) Membentuk suatu sub direktorat di Direktorat Potensi, Kepatuhan, dan Peneimaan yang memiliki fungsi membuat kebijakan terkait penggalian potensi di bidang zakat.

c) Menambahkan fungsi di sub direktorat penilaian sebagai penilai harta zakat

d) Membentu suatu bidang baru di setiap Kanwil DJP yang bertugas untuk melakukan penggalian potensi zakat di wilayahnya masing-masing

e) Membentuk suatu seksi baru di Kantor Pelayanan Pajak yang bertugas untuk melakukan pengawasan atas zakat yang dibayar.

Selain lembaga pemungutan, perlu juga dipikirkan mengenai lembaga yang bertugas mengelola dana zakat dan mendistribusikan zakat kepada pihak yang berhak menerimanya. Saat ini, yang bertugas dalam pengelolaan dan pendistribusian kas negara adalah Direktorat Jenderal Perbendaharaan Negara (DJPB). Guna efisiensi, pemerintah tidak perlu membuat lembaga baru untuk pengelolaan dan pendistrbusian zakat, akan tetapi dapat menggabungkan fungsi pengelolaan dana zakat di DJPB dengan beberapa ketentuan sebagai berikut:

1) DJPB harus dapat memisahkan aset dan kas yang bersumber dari pajak, PNBP, dan Zakat

Pemisahan ini dilakukan agar tidak terjadi pencampuran antara kas yang didapat dari pajak dengan zakat. Bahkan Al-Qardhawi (2011, 743) menyebutkan seharusnya pemerintah memiliki empat baitul maal yaitu baitul mal khusus untuk zakat, baitul mal untuk penyimpanan pajak dan upeti, baitul mal untuk ghonimah dan rikaz, dan baitul mal khusus untuk harta yang tidak ada pemiliknya. Hanya saja, saat ini banyaknya baitul mal tersebut dapat dipenuhi dengan pemisahan rekening yang dimiliki pemerintah di Bank menjadi rekening khusus untuk penerimaan dan pengeluaran dana zakat dan rekening khusus untuk penerimaan dan pengeluaran dana non-zakat. 
Muhammad Reza Ramadhan: Integrasi Pajak dan...

2) DJPB harus menyediakan tempat untuk penyimpanan harta zakat non-kas Berbeda dengan pajak dan PNBP, hasil pemungutan zakat tidak hanya berupa uang kas, tetapi juga berupa barang seperti hewan ternak, emas, dan sebagainya. DJPB harus memikirkan tempat yang dapat menyimpan hasil pemungutan zakat berupa barang sebelum dibagikan kepada masyarkat.

3) DJPB harus membentuk suatu unit kerja baru yang bertugas mendistribusikan harta zakat Saat ini, DJPB, dalam mekanisme pencairan anggarannya menggunakan sistem pasif, maksudnya adalah pengguna anggaran harus aktif untuk meminta pencairan dana APBN kepada DJPB. Sedangkan, untuk pendistribusian zakat, pemerintah tidak hanya menggunakan sistem pasif, tetapi juga harus secara aktif mencari orang yang berhak menerima zakat. Sistem aktif ini dapat dilakukan oleh Kementerian/Lembaga teknis terkait dengan bekerja sama dengan unit kerja baru di DJPB yang bertanggung jawab dalam pendistribusian harta zakat non-kas.

Oleh karena itu, dari penjelasan di atas dapat disimpulkan mengenai arus kerja apabila lembaga zakat terebut berada di bawah kementerian keuangan:

1) Zakat dibayar dan diilaporkan secara self assessment oleh wajib zakat,

2) Besaran zakat yang dibayar harus diawasi oleh petugas pengawas zakat di KPP,

3) Zakat berupa kas akan langsung masuk ke rekening kas negara untuk penampungan dana zakat, sedangkan zakat berupa barang harus disimpan dalam tempat khusus sebelum didistribusikan kepada yang berhak,

4) Kementerian/Lembaga teknis terkait melalui unit khusus pendistribusian zakat harus secara aktif mendistribusikan harta zakat bekerja sama dengan unit kerja di DJPB yang bertanggung jawab atas distribusi harta zakat non-kas, terutama yang berupa harta zakat non-kas, sedangkan untuk belanja pemerintah yang dibiayai oleh zakat, DJPB melakukan mekanisme pencairan anggaran seperti biasa. 
Islamiconomic: Jurnal Ekonomi Islam

Vol.8 No.1 Januari - Juni 2017

\section{Hubungan Antara Zakat Dengan Pajak}

Para ulama sebenarnya sudah banyak yang menjelaskan mengenai sumber pendapatan pemerintah yang dapat digunakan untuk membiayai belanjanya, misalnya Al-Mawardi $(2006,227)$ telah menjelaskan bahwa sumber pendapatan pemerintah dapat berasal dari ghonimah (harta rampasan perang), fai (harta yang didapatkan oleh pemerintah dari negara non-muslim tanpa perang), kharaj (pajak atas tanah), ushur (bea masuk), dan zakat. Akan tetapi, saat ini jenis pendapatan ghonimah serta fai sudah tidak mungkin lagi didapatkan oleh suatu negara, sehingga menurut Chapra $(2001,335)$ pada zaman ini pemerintah dapat membuat jenis pajak baru yang digunakan untuk membiayai pengeluaran pemerintah.

Kemudian para ulama juga telah berselisih pendapat mengenai bolehnya pemerintah memungut pajak lain selain zakat. Sebagian dari mereka membolehkan pemerintah memungut pajak, ini adalah pendapat Al-Qardhawi $(2011,966)$, Chapra (2001, 335), Ibnu Taimiyah dalam Islahi $(1997,254)$, Al-Ghazali dalam Al-Qardhawi (2011,1077), An-Nawawi dalam Al-Qardhawi $(2011,1076)$, dan ulama-ulama lainnya. Sedangkan ulama yang melarang pemerintah memungut pajak kepada rakyatnya adalah Imam Ahmad bin Hanbal sebagaimana dikutip oleh Al-Hanbali $(1993,157)$, kemudian Al-Baghawi $(1983,61)$ serta Asy-Syaukani $(2009,279)$.

Akan tetapi menurut Chapra (2001,337), adanya pendapat yang melarang pemerintah memungut pajak disebabkan karena pemerintah yang ada pada zaman ulama tersebut sewenang-wenang dalam memungut pajak, sehingga rakyat hidup dalam kemiskinan sedangkan pemerintah hidup dalam kekayaan yang berlimpah. Adapun Al-Qardhawi $(2011,1079)$ menjelaskan bahwa pemerintah boleh melakukan pemungutan zakat dengan syarat empat hal berikut terpenuhi:

1. Pemerintah benar-benar sedang membutuhkan uang dan sumber lain tidak dapat memenuhi kebutuhan tersebut,

2. Pembagian beban pajak yang adil diantara masyarakat,

3. Pajak hendaknya digunakan untuk membiayai kepentingan umat bukan untuk maksiat dan hawa nafsu,

4. Pajak harus dipungut dengan kesepakatan para ahli ekonomi dan ulama. 
Muhammad Reza Ramadhan: Integrasi Pajak dan...

Kemudian Chapra $(2001,337)$ juga menjelaskan tentang syarat yang harus dipenuhi agar pemerintah dapat memungut pajak dari rakyatnya yaitu:

1. Pajak harus dipungut hanya untuk membiayai pengeluaran yang benar-benar dianggap perlu dan untuk kepentingan mewujudkan masyarakat yang sejahtera,

2. Beban pajak tidak boleh terlalu memberatkan masyarakat,

3. Hasil dari pajak harus dibelanjakan secara hati-hati dan aapsesuai dengan tujuan awal pemungutan pajak tersebut.

Oleh karena itu, pemerintah Indonesia harus menjaga syarat-syarat tersebut di atas harus terpenuhi dalam penggunaan belanja dalam APBN.

Kemudian, yang menjadi pertanyaan selanjutnya adalah bagaimana hubungan antara zakat dengan pajak? Apakah zakat yang sudah dibayar dapat mengurangi pajak yang terutang? Bakar dan Rahman $(2007,37)$ menjelaskan di negara Malaysia, zakat bisa digunakan sebagai pengurang pajak penghasilan orang pribadi, sedangkan untuk wajib pajak badan, zakat dapat dibebankan sebagai pengurang penghasilan maksimal dua setengah persen dari penghasilan. Sedangkan di Indonesia, zakat dapat dibebankan sebagai pengurang penghasilan maksimal dua setengah persen dari penghasilan baik untuk wajib pajak orang pribadi maupun wajib pajak badan. Dalam periode islam di masa lalu, Al-Mawardi $(2006,261)$ menjelaskan bahwa tanah yang sudah dikenai zakat, tidak boleh dikenai kharaj (pajak atas tanah). Oleh karena itu, dapat disimpulkan dalam periode islam di masa lalu, zakat dapat digunakan sebagai pengurang pajak yang harus dibayar.

Hanya saja, pada dasarnya tidak terdapat dalil yang kuat yang menunjukkan bahwa zakat dapat digunakan sebagai pengurang pajak, dalam praktik periode islam di masa lalu pun, Al-Mawardi $(2006,261)$ hanya menyampaikan mengenai pendapat imam Asy-Syafii tanpa menyebutkan dalil yang tegas dari Alquran, hadis, ijma, maupun qiyas. Oleh karena itu, penerapan hubungan antara zakat dengan pajak mengikuti prinsip umum sebagaimana telah ditegaskan oleh imam An-Nawawi dalam Al-Qardhawi $(2011,1077)$ bahwa dalam hal pemerintah mengalami kekurangan harta untuk membiayai pengelurannya, maka pemerintah dapat memungut pajak dalam bentuk pemungutan selain zakat. Oleh karena itu, boleh atau tidaknya zakat menjadi pengurang pajak yang harus dibayarkan masyarakat bergantung kepada sebesar apa kekurangan harta yang dibutuhkan pemerintah. Apabila kekurangan 
Islamiconomic: Jurnal Ekonomi Islam

Vol.8 No.1 Januari - Juni 2017

tersebut sangat besar, pemerintah dapat membuat aturan yang tidak memperbolehkan zakat digunakan untuk mengurangi pajak yang harus dibayar. Sedangkan, ketika pengeluran pemerintah sudah dapat dibiayai dengan penerimaan dari pajak dikurangi dengan zakat yang telah dibayarkan oleh masyarakat, pemerintah seharusnya membuat suatu aturan mengenai bolehnya zakat digunakan sebagai pengurang pajak yang masih harus dibayar.

\section{Kesimpulan}

Berdasarkan penelitian yang telah dejelaskan di atas, maka dapat ditarik beberapa kesimpulan sebagai jawaban atas pertanyaan penelitian sebagai berikut:

1. Zakat merupakan sumber penerimaan negara yang penting setidaknya dengan tiga alasan, pertama, objek zakat lebih luas dibandingkan dengan objek pajak dimana masih sangat banyak objek zakat yang belum tertangani dengan baik sehingga potensi dari penerimaan zakat yang belum tergali masih sangat besar, kedua, dana zakat juga dapat digunakan untuk membiayai belanja pemerintah, ketiga, motivasi masyarakat yang tinggi dalam pembayaran zakat karena terdapat hubungan spiritual yang terkait dengan hubungan manusia dengan Allah.

2. Pemungutan zakat harus dilaksanakan secara terintegrasi dengan pajak dan dijalankan oleh Direktorat Jenderal Pajak, sedangkan untuk pengelolaan dan penyalurannya dilakukan oleh Direktorat Jenderal Perbendaharaan dengan bekerja sama dengan Kementerian / Lembaga yang terkait. Kemudian untuk hubungan antara kewajiban pajak dan zakat per masing-masing Wajib Pajak pada dasarnya tidak ditentukan secara spesifik dalam hukum islam, akan tetapi hal ini bergantung kepada kebutuhan pemerintah, apabila pemerintah sedang membutuhkan dana yang besar, maka pemungutan zakat dilakukan tanpa dapat mengurangi pajak yang masih harus dibayar, sedangkan apabila pemerintah sedang dalam keadaan tidak membutuhkan dana besar, maka dapat membuat suatu aturan mengenai bolehnya zakat digunakan sebagai pengurang pajak.

\section{Pustaka Acuan}

Al-Hanbali, Ibnu Rajab. 1993. Iqozh ul-Himmam Al-Muntaqo min Jami'il Ulum Wal Hikam. Damam: Dar Ibnu Al-Jauzy 
Muhammad Reza Ramadhan: Integrasi Pajak dan...

Al-Mawardi. 2013. Al-Ahkam As-Sulthaniyyah: Hukum-Hukum Penyelenggaraan Negara dalam Syariat Islam. Penerjemah Fadli Bahri. Bekasi: Darul Falah.

Al-Qardhawi, Yusuf. 2011. Hukum Zakat: Studi Komparatif Mengenai Status dan Filsafat Zakat berdasarkan Alquran dan Hadis. Penerjemah Didin Hafidhuddin, dan Hasanuddin Salman Harun. Bogor: Pustaka Litera Antar Nusa.

Al-Utsaimin, Muhammad bin Shalih. Ushul Fiqih. 2008. Penerjemah Ahmad S. Marzuqi. Yogyakarta: Media Hidayah.

An-Nabhan, M. Faruq. 2000. Sistem Ekonomi Islam: Pilihan Setelah Kegagalan Sistem Kapitalis dan Sosialis. Penerjemah Muhadi Zainuddin dan A. Bahaudin Noersalim. Yogyakarta: UII Press.

At-Tuwaijiri, Muhammad bin Ibrahim. 2012. Ringkasan Fiqih Islam. Penerjemah Eko Haryanto dan Mohammad Latif. Jakarta: Islamhouse.

Bakar, Nur Barizah Abu dan Abdul Rahim Abdul Rahman. 2007. "A Comparative Study of Zakah and Modern Taxation." Journal King Abdul Aziz University vol. 20, 2540 .

BAZNAS. http://pusat.baznas.go.id/ib-peduli/ (diakses 26 Januari 2015).

Chapra, M. Umer. 2001. The Future of Economics: an Islamic Perspective. Penerjemah Amdiar Amir et. al. Jakarta: Shari'ah Economics and Banking Institute.

Islahi, A.A. 1997. Konsep Ekonomi Islam Ibnu Taimiyah. Penerjemah Anshari Thayib. Surabaya: Bina Ilmu.

Salim, Abu Malik Kamal bin As-Sayid. 2006. Shahih Fiqih Sunnah jilid 3. Dialihbahasakan oleh Abu Ihsan Al-Atsari. Jakarta: Pustaka At-Tazkia.

Undang-Undang Nomor 6 tahun 1983 stdd Undang-Undang Nomor 16 tahun 2009 tentang Ketentuan Umum dan Tata Cara Perpajakan

Undang-Undang Nomor 23 tahun 2011 tentang Pengelolaan Zakat

Undang-Undang Nomor 14 tahun 2015 tentang Anggaran Pendapatan dan Belanja Negara 2016

Undang-Undang Nomor 28 tahun 2009 tentang Pajak Daerah dan Retribusi Daerah 